II.

\title{
'N KORT HISTORIESE OORSIG SEDERT DIE KOMS EN VESTIGING VAN DIE BIANKE IN DIE GEBIED.
}

Die Sentraal-Afrikaanse Federasie wat in 1953 tot stand gekom het, is uit die vroeëre Suid- en Noord-Rhodesiè en Njassaland gevorm. Hierdie suiwer binnekontinentale staat word rondoin as volg begrens: in die noorde deur die Belgiese Kongo en T'anganjika; in die ooste deur Tanganjika en PortugeesOos-Afrika; in die suide deur die Unie van Suid-Afrika; in die suidweste en weste onderskeidelik deur Betsjoeanaland-protektoraat en Portugees-WesAfrika.
Uit die beskikbare gegewens blyk dit dat die gebied wat later as Rhodesië bekend geword het in die $10 \mathrm{de}$ eeu al deur Bantoestamme bewoon is en dat hierdie mense deur die eeue heen met Arabiese nedersettings te Sofala en ander plekke langs die ooskus van Afrika handelgedryf het. Pogings wat deur die Portugese, wat teen die einde van die 15de eeu die suidpunt van Afrika omseil het, aangewend is om Zambezia vanaf hulle nedersettings op die ooskus binne te dring met die oog op die verkryging 
van die goudhandel in dié gebied, desnoods deur middel van gebiedsverowering, het op 'n mislukking uitgeloop sodat Rhodesië tot in die 19de eeu 'n land, bewoon deur Bantoestamme, gebly het. Ten minste van die 15de eeu af tot in die 18de eeu was die vernaamste regeerder van hierdie gebied 'n hoofman wat kragtens erfreg geregeer het, bekend as die Monomotapa. Sover vasgestel kan word was sy setel gedurende die vroeëre tydperk in die gebied van die latere Masjonaland. Hoewel die Portugese geen vaste voet in Zambezia kon vind nie, het hulle tog daarin geslaag om gedurende die 16 de en 17 de eeu selkere politieke en handelsverbintenisse met sommige van die Monomotapa's aan te gaan. Die „ryk" van die Monomotapa het ook baie vasalstate omvat, en die finale ondergang van die ryk in die 18de eeu moet veral toegeskryf word aan die onderlinge bloedige stryd wat die stamme byna voortdurend teen mekaar gevoer het, waardeur groot getalsvermindering plaasgevind het, terwyl hulle ook nog die prooi van swart invallers, veral vanuit die suide en die ooste geword het. So iets soos genade het hierdie Bantoe-samelewing nie geken nie en sonder uitsondering is hulle lewens beheers deur bygeloof, toordery, vrees, wreedheid en bloeddorstigheid. In die 19de eeu was daar blykbaar geen verband meer tussen die verskillende stamme nie.

Gedurende die 19 de eeu het die Bantoebevolkingspatroon van Rhodesië verander. In 1837 het die Voortrekkers die Matabele onder Moselikatse beslissend verslaan, waarna laasgenoemde hom noordwaarts gewend, die Limpopo oorgetrek en hom met sy volgelinge in die gebied wat as Matabeleland bekend geword het, gaan vestig het. In Januarie 1870 het Lobengula die nuwe hoof van die Matabele geword en het hy vanuit sy hoofstat, Bulawayo, as onbetwiste heerser opgetree oor 'n gebied wat noordwaarts oor die Zambezi gestrek het en ooswaarts oor die gebied wat deur die Masjonas en ander Makalangastamme bewoon is. Noord van die Zambezi was die westelike gedeelte van die latere Noord-Rhodesië in die hande van die Barotse, terwyl die oostelike gedeelte deur stamme van Xosa-Zuluoorsprong verower is. Onder hierdie stamme was die Angoni die belangrikste en die magtigste. Dit was dan hoofsaaklik met hierdie stamme wat die blankes te doen gekry het toe hulle in die 19de eeu in Rhodesië aangeland het.

Die gebied wat later (in 1907) die naam Njassaland-protektoraat gekry het en wat eintlik maar eers in die 19de eeu onder die aandag van die blankes gekom het, is ook van vroeg af deur Bantoestamme bewoon.

Die 19de eeu het groot verwikkelinge, veral vir die gebied van die latere Suid-Rhodesië meegebring. Dit het begin met die ontdekkingsreise van David Livingstone, Thomas Baines, Karl Mauch, e.a., deur wie se toedoen Europa bekend geword het met die land en sy eienskappe, en veral met die groot mineralerylkdom in dié gebied, wat onmiddellik aandag getrek het. Feitlik onmiddellik nadat Lobengula die hoof van die Matabele geword het, het Baines en sir John Swinburne hom onderskeidelik in 1871 en 1872 genader en sekere regte ten opsigte van minerale in sy 
gebied verkry. Daar is egter feitlik niks gedoen om hierdie regte uit te oefen en die minerale te ontgin nie. Gedurende die jare ' 80 van die vorige eeu, is sake egter bespoedig deur die plaasname van die Europese koloniale wedloop om Afrika en verwikkelinge in Suid-Afrika self. Onder laasgenoemde hoort veral die belangstelling wat Paul Kruger en Cecil Rhodes vir die gebied noord van die Limpopo geopenbaar het.

Wat die wedloop om Afrika betref, sover dit die verhoudinge ten opsigte van Rhodesië en Njassaland bepaal het, was Portugal alreeds in besit van Portugees-Wes- en Portugees-Oos-Afrika. In 1884 het Duitsland 'n protektoraat oor Suidwes-Wes-Afrika afgekondig en gedurende 1884/5 het ook Tanganjika deel van die Duitse koloniale gebied geword. Aan die een kant het die Portugese nie baie van hierdie Duitse uitbreiding gehou nie en was Portugal begerig om die gebied tussen sy twee kolonies aan die wes- en ooskus te bekom. Dit het daartoe gelei dat in $\mathbf{1 8 8 7}$ 'n kaart voor die Portugese wetgewende liggaam gelê is, waarop die gebiedseise van Portugal aangetoon word as strekkende van die weskus van Afrika tot aan die ooskus, insluitende feitlik die hele Rhodesiese gebied en 'n groot deel van $\mathrm{Njassaland.} \mathrm{Portugal} \mathrm{het} \mathrm{dit} \mathrm{gedoen}$ nadat die toestemming van Frankryk en Duitsland daartoe verkry is ten spyte daarvan dat die Duitsers nog steeds gehoop het om Matabeleland in die hande te kry. Die verkryging van bogenoemde en ander gebiede deur Duitsland, het die Britse imperialisme verder aangewakker en toe Portugal met sy groot eis van 1887 kom, het dit ernstige protes teen en ontkenning van die aanspraak deur Brittanje meegebring. Rhodes, draer van Britse imperialisme in Suid-Afrika, het ook sy ö̈ op Sentraal-Afrika gevestig gehad.

In Suid-Afrika was ook omstandighede wat veral Suid-Rhodesië in die gedrang gebring het. Rhodes het alreeds vanaf 1878 die gedagte getroetel om Britse gesag nie net oor die hele Suid-Afrika uit te brei nie, maar ook na die gebiede van Sentraal-Afrika. Die stigting van die republieke Stellaland en Gosen in 1883 was 'n ernstige bedreiging vir Rhodes se ideaal van noordwaartse uitbreiding. Rhodes kon dit onder geen omstandighede toelaat nie, sodat in $\mathbf{1 8 8 5}$ Betsjoeanaland as Britse gebied geannekseer is. Die noodsaaklikheid van hierdie anneksasie blyk uit wat Rhodes self ten opsigte van dié gebied gesê het: "I look upon this Bechuanaland territory as the Suez Canal of the trade of this country, the key of its road into the interior ... . Part with the interior road, and you are driven into the desert". Verder sou die anneksasie van hierdie gebied ook verhinder dat Transvaal en Duitsland (in Suidwes-Afrika) mekanr die hand oor Betsjoeanaland heen reik, waardeur Rhodes se strewe vir goed verydel sou wees. Toe die sg. Groblertraktaat in Julie 1887 tussen die Z.A.R. en Lobengula gesluit is waardeur 'n bondgenootskap ontstaan het, het Rhodes onmiddellik en baie vinnig opgetree om te voorkom dat die Z.A.R. enige invloed in die gebied noord van die Limpopo verkry. Dit was in die tyd van goudontdekkinge, en Lobengula is ook van Portugese kant lastig geval vir goudkonsessies. Rhodes se opvolger as 
kommissaris in Betsjoeanaland, sir Sidney Shippard, het voor hierdie gebeurtenisse al in lewendige korrespondensie met Lobengula verkeer, terwyl J. S. Moffat as Britse resident by Lobengula opgetree het. Die Groblertraktaat het dan ook onmiddellike Britse optrede tot gevolg gehad, nl. die verdrag wat op 11 Februarie 1888 deur Moffat met Lobengula aangegaan is waardeur Rhodes, hoewel nie eiendomsreg nie, van Lobengula verkry het dat laasgenoemde geen grond aan 'n ander persoon of staat sou afstaan en geen verdrag met 'n ander staat sou sluit sonder die toestemming van die Britse hoë kommissaris nie. Sodoende het Rhodes die alleenreg oor Matabeleland verkry.

Onder leiding van Rhodes en met goedkeuring van die Britse regering het Rudd, Rockfort, Maquire en Thomson in Okt. 1888 'n ooreenkoms met Lobengula aangegaan waarin laasgenoemde in ruil vir $£ 100$ per maand, 1000 Martini Henry-gewere en 100,000 patrone, aan hulle sindikaat alle beheer oor minerale in sy gebied asook die reg om alle fortuinsoekers uit sy land te weer, verleen het. Daarop het Rhodes onmiddellik begin om sy groot onderneming van stapel te stuur, $\mathrm{nl}$. die flotering van die British South African Company met 'n kapitaal van $\mathfrak{1}, 000,000$. Die doel van die B.S.A. Company is duidelik in die aansoek om 'n oktrooi wat aan die Britse regering voorgelê is uiteengesit:

(a) uitbreiding van die telegraaf- en spoorwegstelsel noordwaarts in die rigting van die Zambezi;

(b) aanmoediging van immigrasie en kolonisasie; (c) bevordering van die handel;

(d) die ontginning van minerale en uitoefening van ander konsessies onder die beheer van een groot magtige maatskappy om mededinging te voorkom en om aan die naturellehoofde en hulle onderdane die regte wat in die onderskeie konsessies vervat word te verseker. Die grense van die gebied waarin die Maatskappy sou optree, is opsetlik ietwat vaag aangedui. In Oktober 1889 het die Britse regering die gevraagde Oktrooi verleen, en van toe af was die B.S.A. Company algemeen as die Chartered Company bekend. Deur die Oktrooi het die Britse regering besonder uitgebreide en selfs soewereine regte aan die Company toegeken. Onder andere is aan die Company die reg verleen om die binneland noordwaarts te koloniseer en dit te regeer d.m.v. wette wat die Company self kon maak, die instelling van 'n polisiediens, die uitoefening van regspraak, toekenning van grondregte en die uitgee van mineralekonsessies. Hierdie regte het dus veel verder gestrek as die ooreenkoms wat met Lobengula aangegaan is. Die presiese grense van die gebied waarin die Company sou optree is later op internasionale basis gereël tussen Brittanje en Duitsland (1900), Portugal (1891) en die Kongostaat (1891). Deur hierdie ooreenkomste is die Britse invloedsfeer dus noordwaarts na die Tanganjikameer uitgebrei.

Die Chartered Company het dadelik aan die werk gespring. Die spoorweg vanaf Kaapstad oor Kimberley is noord. waarts verleng, en as eerste stap is 'n deel van die gebied wat deur die Oktrooi 
aan hom toegeken is in besit geneem. Die keuse het op Masjonaland geval omdat die deel nie juis deur die Matabele bewoon is nie, maar deur 'n aantal vreedsame stamme. In Junie 1890 het kol. Pennefather aan die hoof van 'n pioniersmag ( 500 berede polisie en 180 man van die pionierskorps, almal vrywilligers) vir die doel na Masjonaland vertrek, met die bekende reisiger, F. C. Selous, as gids. Sonder enige noemenswaardige voorvalle en sonder om een enkele skoot te skiet het Pennefather binne enkele maande die plek bereik waar Salisbury as hoofstad aangelê is. Archibald Ross Colquhoun is as eerste administrateur van die gebied benoem. Kort daarna, in Mei 1891, het moeilikhede met die Portugese oor 'n eis t.o.v. 'n stukkie grond op die Portugese noordwes-grens waarin 'n Portugese handelspos geleë was, tot die eerste skermutseling gelei, waarin die B.S.A. Company se polisie geseëvier het. Aan die pioniers is plase en mynkleims in Masjonaland uitgegee. Een nadeel, nl. dat Kaapstad die enigste beskikbare hawe vir die gebied was, is deur Rhodes besef en op sy inisiatief het Brittanje in die 1891-ooreenkoms met Portugal die reg verkry dat 'n spoorweg van Beira of na Salisbury gebou kon word. Verder is voorsiening gemaak vir vrye skeepvaart op die Zambezi en die oprigting van 'n telegraafdiens. Die prospekteerwerk het ook goeie resultate gelewer en ten spyte van aanvanklike koorsprobleme in die laagliggende dele, is gesondheidstoestande spoedig aansienlik verbeter, veral a.g.v. beter huisvesting. Binne twee jaar was alreeds sowat 3,000 blankes in hierdie nuutverkreë gebied gevestig.

Hoewel mededinging van buite af uitgeskakel was, het die Company spoedig met binnelandse moeilikhede te doen gekry toe die Matabele, wat gereelde strooptogte teen die Masjonas onderneem het, in Julie 1893 Masjonaland binnegeval en selfs hulle opwagting in die strate van die nuutaangelegde Victoria gemaak het. Die vyandige houding van die Matabeles het vir die Company niks goeds voorspel nie, en na raadpleging van Rhodes het dr. L. $\mathrm{S}$. Jameson (administrateur te Salisbury as opvolger van Colquhoun) besluit om met sy beskikbare mag (ongeveer 700 vrywilligers, 225 Brits-Betsjoeanalandse polisie en ongeveer 700 naturelle) na Bulawayo, hoofstat van Lobengula, te marsjeer om die Matabele te onderwerp. Verder sou hy deur 'n Betsjoeanamag onder Khama bygestaan word. $\mathrm{Na}$ etlike gevegte teen Matabele-oormagte het die moderne wapens van die blankes die deurslag gegee en is Bulawayo op 3 November 1893 bereik. Lobengula en sy volgelinge het in die rigting van die Zambezi gevlug en in Januarie 1894 is hy naby dié rivier oorlede. So het die Company dan ook administratiewe gesag oor Matabeleland gekry en is die gebied feitlik onmiddellik vir blanke bewoners oopgestel. 'n Nuwe dorp, Bulawayo, wat besonder vinnig gegroei en in belangrikheid toegeneem het, is naby Lobengula se hoofstat aangelê. Die Romeins-Hollandse reg is vir die nuwe kolonie, waarin baie Afrikaanse boere hulle gaan vestig het, aanvaar, 'n grondkommissie 
is aangestel en kommissarisse is benoem om oor die belange van die Bantoes te waak.

In die B.S.A. Company se gebied noord van die Zambezi is ook aansienlike vordering gemaak toe tussen $\mathbf{1 8 8 9}$ en 1891 verdrae met 'n hele aantal Bantoestamme tussen die Njassa- en Tanganjikameer en die Zambezi gesluit is. 'n Nedersetting, Abercorn, is ook aan die suidpunt van Tanganjika aangelê. Die doel van hierdie aksie was om sekere Duitse agente wat die gebied ten weste van die Njassameer na die grens van die Kongostaat wou binnedring, voor te keer. Die Company het verder daarin geslaag om die belange van die African Lakes Corporation oor te neem. Laasgenoemde maatskappy het veral veel gedoen om aan die Britte die belangrikste posisie in die Njassagebied te laat kry. Toe Njassaland in 1891 as 'n Britse protektoraat georganiseer is, het die Company 'n jaarlikse bedrag van $£ 10,000$ vir drie jaar tot die administrasie bygedra, terwyl die Britse kommissaris in dié gebied vir dieselfde tydperk ook as administrateur van die Company se aangrensende gebiede opgetree het. In Junie 1890 het die Barotsehoof ook sy gebied onder die beskerming van die Company geplaas in ruil vir die minerale regte, terwyl die Company onderneem het om nie met die interne administrasie van Barotseland in te meng nie. Hierdie stap is deur Rhodes gedoen om 'n ooswaartse uitbreiding van PortugeesAngola te voorkom. Die ontginning en ontwikkeling van Barotseland, wat gevolg het, het redelik los gestaan van gebeurtenisse in ander dele van Rhodesië.
In 1895 is aan die gebied van die Company die naam Rhodesië ter ere van Cecil Rhodes gegee. In hierdie jaar was die ontginning van Matabeleland op groot skaal aan die gang. Bulawayo het binne nege maande na sy ontstaan 1900 blanke inwoners gehad, terwyl ongeveer 2,000 prospekteerders hulle oral in die goudvelde bevind het. Teen die einde van 1895 was daar alreeds ongeveer 1500 myl telegraaflyne aangelê; die spoorweg van Kaapstad af het alreeds verby Mafeking gestrek en het 'n punt na aan die Rhodesiese grens bereik, terwyl ook aan die spoorweg tussen Salisbury en Beira gewerk is. Die Company het voorwaar geen gras onder hulle voete laat groei nie.

Gebeurtenisse in die jaar 1896 het groot verwikkelinge m.b.t. Rhodesië meegebring. In Nov. 1895 is die BritsBetsjoeanalandse kroonkolonie by die Kaapkolonie aangeheg en het die Company die begeerte uitgespreek om die administrasie van die Betsjoeanalandprotektoraat oor te neem. Laasgenoemde gebied was tussen die by die Kaapkolonie aangehegte gebied en Matabeleland geleë en die spoorweg na Bulawayo sou daardeur gaan. Die Britse regering het geen beswaar gehad nie en terwyl reëlings vir die cordrag van die gebied aan die gang was, is ' $n$ aantal polisie van die Company na Pitsani verskuif. Van hier af het Jameson sy bekend "raid" in Desember 1895 van stapel gestuur, 'n gebeurtenis wat alle verdere reëlings om die protektoraat aan die Company oor te dra skipbreuk laat ly het. Rhodes het ook a.g.v. die gebeurtenis as besturende direkteur bedank, terwyl Jameson op 8 Jan. 1896 van sy amp as administrateur 
van die Company se gebiede onthef en deur graaf Grey opgevolg is. Hierdie terugslag wat die Company ondervind het, is opgevolg deur die runderpes van 1896 wat feitlik die algehele uitwissing van die veestapel in Suid-Rhodesië tot gevolg gehad het, die Masjonalandrebellie (1896-1897) en veral die baie ernstige Matabele-opstand (1896), wat alleen deur die persoonlike optrede van Rhodes tot 'n einde gebring is. Hierdie opstande het die Company ongeveer $£ 2,500,000$ gekos. In April 1898 is Rhodes weer as direkteur van die Company gekies.

Die Jameson-raid en inboorlingrebellies van 1896 het die Britse regering daartoe gebring om ander konstitusionele reëlings vir Rhodesië te tref. Die gewapende magte van die Company was alreeds onder direkte beheer van die Kroon geplaas. Op 29 Okt. 1898 is die toekomstige beheer oor die gebied deur 'n bevel-in-rade sodanig gereël dat 'n resident-kommissaris deur die Britse regering benoem word. Hy sou ampshalwe lid van die uitvoerende en wetgewende raad wees, maar sonder stem. Deur hierdie bevel-in-rade, gewysig deur bevele-in-rade van 1903 en 1905 , sou die administrasie van Rhodesië deur die Chartered Company voortgesit word. Vir Suid-Rhodesië moes die Company 'n administrateur of administrateurs benoem. 'n Uitvoerende raad, bestaande uit nie minder as vier lede nie, moes deur die Company aangestel word om die administrateur in alle sake van belang m.b.t. die administrasie te adviseer. Die bevel-in-rade van 1898 het ook voorsiening gemaak vir 'n wetgewende raad, saamgestel uit vyf genomineerde en vier gekose lede. Die eerste vergadering van hierdie raad het op 15 Mei 1899 in Salisbury plaasgevind. Die samestelling van die Raad is in 1903 gewysig sodat dit voortaan sou bestaan uit die administrateur as voorsitter, sewe lede deur die Company genomineer met goedkeuring van die sekretaris van staat, en sewe lede gekies deur die geregistreerde kiesers, waarvan daar in 1908 al 5291 was. In 1907 is die getal genomineerde lede met een verminder, sodat die gekose lede die meerderheid gevorm het. Die taak van bogenoemde resident-kommissaris sou wees om die hoë kommissaris met alle sake van belang op hoogte te hou. Ordonnansies van die wetgewende raad moes vir goed- of afkeuring aan die hoë kommissaris voorgelê word en al sou dit sy goedkeuring geniet, kon die sekretaris van staat dit nog afkeur. Verder is ook vir die regspraak voorsiening gemaak deur die instelling van 'n hoërhof met twee regters wat oor burgerlike en kriminele jurisdiksie beskik het. Sewe magistraatshowe sou die hele gebied bedien. 'n Sekretaris vir naturellesake, bygestaan deur twee hoofnaturellekommissarisse, 28 naturellekommissarisse en ses assistent-naturellekommissarisse, sou vir die behartiging van naturellesake verantwoordelik wees. Die Company moes ook voorsiening maak vir genoegsame en geskikte grond vir die naturelle om te bewoon en om in hulle landbou- en industriële behoeftes te voorsien.

$\mathrm{Na}$ die dood van Rhodes in 1902 het daar onder die Rhodesiërs 'n sekere mate van ontevredenheid met die behartiging van sekere sake deur die Company ontstaan. Die Company was 
gewillig om die administrasie van die gebied onder behoorlike voorwaardes aan die koloniste oor te dra en is die ondersoek van só 'n moontlikheid opgedra aan sir George Goldie, wat Rhodesië in 1903/4 besoek en 'n moontlike skema daarvoor uitgewerk het. Dit is egter ná 'n samespreking tussen leidende Rhodesiërs en direkteure van die Company verwerp, omdat die finansiële las wat so 'n oordrag van administrasie sou meebring as te swaar vir so 'n jong kolonie beskou is. Griewe teen die administrasie van die Company het egter bly voortbestaan ten spyte van belangrike ontwikkelinge wat in Rhodesië plaasgevind het, sodat dr. Jameson, destyds eerste minister van die Kaapkolonie, in 1907 saam met ander direkteure van die Company 'n besoek aan Rhodesië gebring het om dié griewe te ondersoek, dit uit die weg te probeer ruim en weë vir groter produksie te beplan. Suid-Rhodesië wat alreeds 'n selfonderhoudende gebied was, is nog nie as ryp genoeg beskou om 'n selfregerende kolonie te word nie, en om die vernaamste griewe tegemoet te kom, is die verkryging van landbougrond makliker en goedkoper gemaak en is regeringsadvies en -bystand aan landbouers en veeboere beskikbaar gestel. Tabakkwekery is aangemoedig, wat so ingang gevind het dat tabak ter waarde van byna $£ 35,000$ alreeds in 1911 uitgevoer is. Belangrike spoorweguitbreidings is ook onderneem terwyl aan industriële en veral mynondernemings toenemende aandag geskenk is, sodat Rhodesiese gouduitvoer in 1909 meer as $£ 2,500,000$ bedra het. Selfs gedurende die Eerste Wêreldoorlog, toe Rhodesië 'n aansien- like mannekrag tot die Britse magte bygedra het, is die algemene vooruitgang in die gebied nie gestrem nie, maar het dit inteendeel nog verder toegeneem.

In Oktober 1914 was die 25 jaar waarvoor die Oktrooi voorsiening gemaak het, verstreke en het dit die einde van die Company se administrasie beteken. Daar moes nuwe reëlings getref word en daar was verskillende weë oop.

(a) Een weg was om saam met die vier Suid-Afrikaanse kolonies wat in 1910 die Unie van Suid-Afrika gevorm het, in 'n eenheid betrek te word. Weliswaar het die nouer verenigingspogings in Suid-Afrika die belangstelling van veral Suid-Rhodesië geniet, sodat Rhodesiese verteenwoordigers die vergaderinge van die Nasionale Konvensie in 1908/9 bygewoon het. Hoewel Rhodesië nie tot die Unie toegetree het nie, is in die Imperiale wet van 1909 in elk geval vir sodanige vrywillige toetrede voorsiening gemaak wanneer Rhodesië sy voorneme in dié verband te kenne sou gee.

(b) Die tweede weg was om te probeer om die Oktrooi vir 'n volgende tydperk verieng te kry terwyl

(c) die derde was om pogings aan te wend om 'n selfregerende kolonie te word.

In 1913 is ernstige pogings aangewend om aan die derde moontlikheid uitvoering te gee maar, soos voorheen, is soveel moeilikhede in die verband voorsien dat elf van die twaalf gekose lede van die wetgewende vergadering in Maart 1914 van gevoele was dat die Company se administrasie altans vir 'n tydlank voortgesit moes word. ' $n$ 
Maand later het die Vergadering 'n duidelike beleid bepaal: die reg van die koloniste op selfregering is erken en in beginsel aanvaar, en ondersoek sou ingestel word na welke inkomstebronne die Company aan 'n administrasie wat dit sou opvolg, kon oorhandig. Onder hierdie omstandighede het die Britse regering toegestem en besluit om die Oktrooi van die Company met tien jaar te verleng, met die voorbehoud, waartoe die Company toegestem het, dat verantwoordelike bestuur aan Rhodesië gegee moes word voor verstryking van die tien jaar, as en wanneer die koloniste sou kon toon dat hulle in staat is om die administrasie van die kolonie oor te neem.

Vir die direkteure van die Company het dit 'n groot probleem meegebring. Hulle was heeltemal bereid om die beheer oor die gebied aan die koloniste oor te dra, maar aan die ander kant moes die belange van die aandeelhouers in aanmerking geneem word. Een van die probleme was dié van eiendomsreg t.o.v. die onvervreemde grond. Die Company wou hierdie grond graag verkoop om te vergoed vir die bedrag wat aan administrasie gespandeer is en wat veel hoër was as die inkomste wat reeds vir die doel ingesamel was. In 1913 het die Company al verklaar dat genoemde grond, tesame met die mineraleregte en spoorwegbelange daarop, sy eiendom was. Die wetgewende vergadering het daarteenoor gestel dat ook hierdie grondgebied by verstryking van die Company se bestuur saam met die administrasie aan die kolonie oorgedra moes word. Hierdie verskil is in 1918 deur 'n Privy Council-beslissing versoen, nl. dat aangesien die onvervreemde gebied kroongrond was, die Company die reg gehad het om dit te verkoop totdat vir sy administratiewe verliese vergoed is. In 1921 het die Cave-kommissie, wat 'n koninklike kommissie was, die bedrag waarop die Company aldus geregtig was op byna $£ 4,500,000$ gestel. In 1922 is aansluiting by die Unie van Suid-Afrika weer op die voorgrond gestel en wel op aanbeveling van die Buxtonkomitee en in antwoord op 'n versoekskrif van Rhodesiërs wat ten gunste van sodanige aansluiting was. 'n Ontwerpgrondwet vir verantwoordelike bestuur en die voorwaardes wat deur genl. Smuts aangebied is waarop Suid-Rhodesië by die Unie kon aansluit, is in dié jaar aan die beslissing van die kiesers voorgelê. Die uitslag van die referendum is nogal interessant as in aanmerking geneem word dat 5,989 ten gunste van aansluiting by die Unie was teenoor 8,774 wat hulle ten gunste van die toekenning van verantwoordelike bestuur aan die kolonie verklaar het. Hierdie tweespalt het die inmenging van die Britse regering uitgelok. Die Company het hom bereid verklaar om ter voldoening van sy administratiewe eise t.o.v. Noord- sowel as SuidRhodesië die bedrag van $£ 3,750,000$ (i.p.v. bg. byna $£ 4,500,000$ ) te neem. Die Company het egter sy mineraleregte behou en ook die versekering gekry dat hierdie regte en sy spoorwegbelange deur die regering wat sou kom, gerespekteer sou word. Die bedrag van $£ 3,750,000$ ( $£ 2,000,000$ verliry deur 'n lening is deur Suid-Rhodesië betaal terwyl die res deur Brittanje geskenk is) is in Okt. 1923 betaal, sodat die ver. 
naamste struikelblok vir die toekenning van verantwoordelike bestuur aan SuidRhodesië uit die weg geruim is.

Suid-Rhodesië het sy konstitusie op 1 Okt. 1923 van die Britse regering ontvang. Voortaan sou hierdie gebied verantwoordelike bestuur geniet, maar op wetgewing t.o.v. die naturellebevolking, die onvervreemde grond, spoorweë en die mineraleregte van die Company, kon die Kroon die vetoreg toepas. Die wetgewende gesag is geplaas in die hande van die Kroon, verteenwoordig deur die goewerneur, 'n uitvoerende raad bestaande uit die ministerie onder voorsitterskap van die goewerneur en verantwoordelik aan die wetgewende vergadering. Laasgenoemde vergadering sou bestaan uit 30 gekose verteenwoordigers uit 11 kiesafdelings. Die eerste algemene verkiesing is op 29 April 1924, gehou, waarna die eerste ministerie met sir Charles Coghlan as eerste minister gevorm is. Stemreg is tot alle Britse onderdane uitgebrei, met insluiting van naturelle bo die ouderdom van 21 jaar en in besit van eiendom ter waarde van meer as

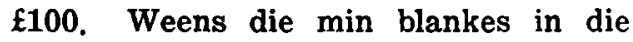
gebied is onmiddellik aan die saak van immigrasie aandag gegee, sodat die blanke bevolking in die komende jare besonder vinnig uitgebrei het. In 1926 bv. was die sensussyfer vir blankes in dié gebied ongeveer 39,000 , terwyl die geskatte getal twee jaar later op ongeveer 50,000 gestel is.

Noord-Rhodesië, ongeveer twee keer so groot as Suid-Rhodesië, was tot 1911 in Noordwes-Rhodesië en NoordoosRhodesië verdeel, onder beheer van die B.S.A. Company. Sedert 1911 is die gebied as een geheel geadministreer, nl. as Noord-Rhodesië. In 1924 is dit deur die Britse regering van die Company oorgeneem en het dit 'n Britse protektoraat geword, geadministreer kragtens 'n konstitusie wat by wyse van 'n bevel-in-rade daaraan verleen is, en met H. J. Stanley as eerste goewerneur. Die gesag van naturellehoofmanne is soveel as moontlik gehandhaaf en 'n blanke magistraat is in elkeen van die ses distrikte waarin die protektoraat verdeel is, gestasioneer. Barotseland is as naturellereserwe verklaar, tradisioneel geregeer deur die opperhoof bygestaan deur 'n raad van mindere hoofde. NoordwesRhodesië het in belangrike opsig van Noordoos-Rhodesië verskil. In eersgenoemde was $85 \%$ van die blankes woonagtig en het dit ook die regeringsetel gehuisves, terwyl die blanke bevolking van Noordoos-Rhodesië hoofsaaklik uit 'n paar honderd nedersettertabakplanters bestaan het. Vir 'n lang tyd was die twee gebiede ook van mekaar geskei deur 'n feitlik totale afwesigheid van verkeersverbindinge. Daarbenewens was die Company se aandag altyd meer op Suid-Rhodesië toegespits, sodat blanke bewoning van Noordoos-Rhodesië nie juis daardeur aangemoedig is nie en hierdie gebied se ontwikkeling gevolglik daaronder gely het.

Oorspronklik het Njassaland 'n deel van die gebied wat as Brits-sentraalAfrika bekend is uitgemaak. Vroeër in die 19de eeu is hierdie benaming van Brits-sentraal-Afrika deur sir $H$. $H$. Johnston van toepassing gemaak op al die gebiede onder Britse invloed, noord van die Zambezi, wat vroeër bestem 
was om deur een administrasie behartig te word. Verloop van gebeurtenisse het egter die aansluiting van Barotseland en ander Rhodesiese gebiede by die direk geregeerde Britse gebiede noord van die Zambezi verhoed. Gevolglik is die naam Brits-sentraal-Afrika in 1893 amptelik gegee aan die Britse protektoraat op die Shirérivier en rondom die Njassameer. In 1907 is die amptelike benaming van die protektoraat tot dié van Njassalandprotektoraat verander, terwyl die gebied van die B.S.A. Company noord van die Zambezi Noordoos- en Noordwes-Rhodesië genoem is.

Van die geskiedenis van Njassaland voor ongeveer die helfte van die $19 \mathrm{de}$ eeu is min bekend. Gedurende die 16de en 17 de eeu het enkele Portugese avonturiers die gebied binnegedring en behalwe dat hierdie reise met 'n taamlike vaagheid omhul is, het hulle ook niks van betekenis uitgerig nie. Sover dit blanke indringing in die gebied betref, begin die geskiedenis van Njassaland eers met die optrede van die Britse sendeling - ontdeklkingsreisiger, David Livingstone, wat in 1859 die gang van die Shirérivier gevolg en die Njassameer ontdek het. Die reise van Livingstone wat hierop tot met sy dood in 1873 gevolg het, was vir die bekendwording van die gebied rondom die Njassameer verantwoordelik asook dat Britse belange daarin gevestig geraak het. $\mathrm{Na}$ Livingstone se dood het verskeie sendinggenootskappe sendelinge daarheen gestuur, en hierdie sendelinge het saam met 'n groepie Skotse nedersetters besliste teenstand gebied teen die pogings van die Portugese om hulle invloed en beheer vanuit Mosam- biek en die Zambezi in hierdie rigting uit te brei. Uit die sendinggenootskappe het 'n handelsmaatskappy voortgekom, nl. die African Lakes Trading Corporation, wat weer met 'n aantal Arabiere wat hulle aan die noordekant van die Njassameer gevestig het, in botsing gekom het. Die stryd tussen Arabier en Brit om die besit van die Njassagebied, het vanaf 1885 tot 1895 aangehou. Die African Lakes Corporation het vir hierdie nie-amptelike oorlog van die dienste van vrywilligers gebruik gemaak, o.a. ook van die van kapt. (later sir) F. D. Lugard en mnr. (later sir) Alfred Sharpe. In 1889 is mnr. (later sir) H. H. Johnston uitgestuur om te probeer om die strydpunt tussen die African Lakes Corporation en die Arabiere op te los en om terselfdertyd die beskerming van vriendskaplike naturellehoofde teen Portugese aggressie te verseker. Die resultaat van hierdie pogings en verdrae wat gesluit is, was die totstandkoming van die Britse protektoraat en invloedsfeer noord van die Zambezi. In 1891 is Johnston na dié gebied as imperiale kommissaris en konsul-generaal teruggestuur. Tussen 1889 en 1891 . het Sharpe namens Rhodes 'n groot deel van die landstreek by wyse van 'n verdrag met die B.S.A. Company verbind en is hierdie gebied (Noord-Rhodesië) vir vier jaar lank deur sir Henry Johnston in verbinding met die Brits-sentraal-Afrikaanse protektoraat geadministreer. Tussen 1891 en 1895 is die lang stryd met die Ara. biere voortgesit, hoofsaaklik met die oog op die onderdrukking van die slawehandel en is hierdie stryd in 1896 beëindig toe die laaste vesting van die Arabiere 
ingeneem is. Tussen 1896 en 1898 het oorloë met die Angonistamme gevolg en eers nadat hulle onderwerp is en die Company die opstandige Awemba en Bashakulumbwestamme tot orde gebring het, het daar vir hierdie landstreek 'n redelike hoop op vrede en vooruitgang aangebreek.

In 1897 het Sharpe vir Johnston, wat na Tunisië verplaas is, as kommissaris opgevolg. In 1904 is die administrasie van dic protektoraat wat tot tdusver nog deur die Foreign Office behartig is, na die Koloniale kantoor oorgedra en toe die naam van die protektoraat in 1907 verander is, is die hoofadministratiewe beampte se pos van kommissaris tot goewerneur verander. Terselfdertyd is ook 'n uitvoerende en wetgewende raad ingestel. Onder die bewind van Sharpe, wat in 1910 as goewerneur afgetree het, is groot vooruitgang gemaak terwyl veral die Livingstonia Mission of the United Free Church vir baie jare werk van onskatbare waarde onder die inboorlinge verrig het.

Sharpe is in 1911 deur sir W. H. Manning as goewerneur opgevolg. Hy is veral bekend vir die oprigting van die Sentraal-Afrikaanse regiment. In 1913 is hy na Jamaica verplaas en het mnr. (later sir) George Smith goewerneur geword. Toe die Eerste Wêreldoorlog in 1914 uitgebreek het, was die protektoraat in 'n algeheel onverdedigde posisie en is dit deur die Duitsers vanuit Oos-Afrika aangeval, maar die Nyassaland Volunteer Reserve wat deur die Goewerneur inderhaas op die been gebring is, bygestaan deur 'n kontingent van ongeveer 1000 man vanuit Suid-Afrika in September 1915, het
Njassaland van besetting deur die Duitse magte gered. Later het die gebied selfs die basis gevorm vanwaar genl. Northey sy operasies teen die Duitsers van stapel gestuur het.

In 1915 is sake nog verder vertroebel toe 'n naturelleopstand van beperkte omvang in die Shiré-hooglande uitgebreek het. Die leier daarvan was John Chilembwe, 'n naturel wat deur die Amerikaanse Baptiste-sending as onderwyser opgelei en na die V.S.A. vir universitêre studie gestuur is. $\mathrm{Na}$ sy terugkeer het hy 'n kerk gebou en die onafhanklikheid van die Bantoe gepredik. Die opstand is egter maklik onderdruk en Chilembwe is deur 'n polisiekoeël gedood toe hy gevlug het.

Baie blankes wat vanuit Brittanje en Suid-Afrika gekom het om teen die Duitsers te veg, het in Njassaland as nedersetters agtergebly, wat weer 'n uitbreiding van landbougebied tot gevolg gehad het. In 1920 het dié gebied 'n ernstige ekonomiese krisis beleef, veroorsaak deur 'n skerp daling in die prys van produkte gelyktydig met die heffing van 'n hoë uitvoerbelasting op katoen, tee en tabak. Teen hierdie tyd was dit ook duidelik dat Njassaland se toekoms tot 'n groot mate van die voltooiing van ononderbroke spoorwegverbindings vanaf die Njassameer tot aan die see afhanklik was. Sedert die einde van die Eerste Wêreldoorlog is verskeie pogings aangewend om die Njassalandprotektoraat met aangrensende Britse gebiede te amalgameer, eers met Kenia en Tanganjika, en na 1938 met Rhodesië.

Die gedagte wat alreeds in $\mathbf{1 9 1 4}$ geopper is om Noord- en Suid-Rhodesië 
met mekaar te amalgameer het in 1927 weer op die voorgrond getree met die benoeming van die Hilton Youngkommissie. Met die amptelike standpunt van die Britse regering dat Noord-Rhodesië onder die groep van die OoskusBritse kolonies geklassifiseer word, kon hierdie kommissie hom nie in sy rapport (1929) vereenselwig nie. Daarom het die kommissie aanbeveel dat ,in the present state of communications the main interests of Nyassaland and Northern Rhodesia, economic and political, lie not in association with the Eastern African territories but rather with one another and with the selfgoverning colony of Southern Rhodesia". Verder word aanbeveel dat die reeds bestaande samewerking tussen die noordelike gebiede, Njassaland, NoordRhodesië en Zanzibar moes bly voortbestaan.

Hierdie gedagte van 'n nouere vereniging tussen Suid- en NoordRhodesië en Njassaland het bly voortbestaan. In 1938 is die hele saak weer deeglik deur 'n koninklike kommissie onder oë geneem, maar kon ook hierdie kommissie nog niks meer aanbeveel as dat 'n inter-territoriale adviesraad vir die gebiede ingestel moes word nie. Die Tweede Wêreldoorlog het die instelling van dié raad egter vertraag tot in 1945, toe die sg. Central African Council tot stand gekom het, 'n raad wat in 1951 weer tot 'n blote sekretariaat verlaag is. In 1944 , voor die instelling van genoemde raad, was die saak van nouere aaneensluiting ook nog sterk ter sprake, veral ook vanweë die gevoel wat veral in Suid-Rhodesië ten gunste van 'n aaneensluiting bestaan het, maar die Britse sekretaris vir kolonies, kol. Oliver Stanley, het aangekondig dat, na inagneming van alle sienswyses, die vereniging van die gebiede nog geen praktiese stap sou wees nie.

In Maart 1951 het 'n konferensie van amptenare in Londen 'n federasie van die drie gebiede aanbeveel onder die naam Brits-sentraal-Afrika, met 'n sentrale gesag in beheer van buitelandse sake, verdediging en ekonomie. $O p$ hierdie voorstel is deeglik ingegaan op 'n konferensie wat in Sept. 1951 by die Victoriavalle deur verteenwoordigers van dié gebiede en die Britse sekretaris vir kolonies gehou is. Naturelle-afgevaardigdes vanuit die noorde was teen so 'n federasie gekant, terwyl alle ander belangegroepe en die Britse Arbeidersregering federasie in beginsel aanvaar het. Toe die Konserwatiewe regering in Oktober 1951 weer aan bewind gekom het, het ook hulle verklaar dat federasie alleen die belange van al die inwoners van die betrokke gebiede op die allerbeste wyse kon dien. Daarop is in April 1952 weer 'n konferensie in Londen gehou, waar 'n konsep konstitusionele skema bespreek en goedgekeur is. Kommissies is benoem om ondersoek in te stel en rapport te lewer oor sekere aspekte rakende die geldsake, regswese en staatsdiens van die beoogde federasie. Die naturelleafgevaardigdes van NoordRhodesië en Njassaland het geweier om hierdie konferensie by te woon en het voortgegaan om die voorgenome federasieskema teen te werk. Die bal was in elk geval aan die rol en dit sou nie lank duur voordat finaliteit bereik sou word nie. 
In Januarie 1953 is die finale konferensie i.v.m. die federasie gehou. Daarna is twee witboeke gepubliseer $\mathrm{nl}$. The Federal Scheme en Report by the Conference on Federation. Dit was die oortuiging van die konferensie dat 'n hegter politieke en ekonomiese vereniging vir. die drie betrokke gebiede essensieel was as hulle hulle hulpbronne ten volle wou ontwikkel. Suid-Rhodesië sou in die federasie sy verantwoordelike bestuur behou en die ander twee gebiede sou elkeen ook 'n eie regering hê onder die spesiale beskerming van die Verenigde Koninkryk. Gedurende die eerste tien jaar van die federasie se bestaan sou geen wysiging in die verdeling van mag. te tussen die federasie en die gebiede aangebring word sonder toestemming van die wetgewende vergadering van al drie gebiede nie. Hersiening van die konstitusie teen die einde van dié tydperk is in die vooruitsig gestel. Aan die hoof van die federale regering is 'n goewerneur-generaal gestel, terwyl daar ook 'n federale parlement sou wees. Totdat by wyse van federale wetgewing daaroor beslis sou word, sou Salisbury die setel van die federasie wees.

Op bogenoemde voorstelle het verskillende reaksies gevolg. In die
Suid-Rhodesiese referendum het 25,570 persone hulle ten gunste van federasie en 14,729 hulle daarteen uitgespreek. In Noord-Rhodesië het die naturelle hulle veldtog teen federasie verskerp, maar die wetgewende raad van dié gebied het die federasiemosie met 17 teen 4 stemme goedgekeur. Njassaland was só teen federasie gekant dat sekere hoofde uit die gebied in Januarie 1953 na Londen gegaan het om duidelike protes teen die hele skema aan te teken. Die opperhoof van Barotseland het tot federasie toegestem op voorwaarde dat sy tradisionele regte gehandhaaf sou word.

In Maart 1953 het die federasievoorstelle en alles wat daarmee saamhang voor die Britse parlement gedien en is 'n mosie van die Opposisie om die hele skema te staak met meerderheid van stemme (304 teen 260) verwerp. In Julie van daardie jaar is die wetgewing finaal afgehandel i.v.m. die totstandkoming van die Sentraal-Afrikaanse Federasie en is bepaal dat die eerste federale verkiesing in Desember 1953 sou plaasvind.

\section{J. S. DU PLESSIS.}

P.U. vir C.H.O.

(Word vervolg). 